\title{
Reflection of Ideology: A Critical Discourse Analysis of Donald Trump's Declaration Speech of Jerusalem as Capital City of Israel
}

\author{
Widyo Andana Pradiptha ${ }^{1}$, Tuti Purwati ${ }^{2}$, Chusni Hadiati ${ }^{3}$ \\ Jenderal Soedirman University \\ widyoandan@gmail.com¹ ${ }^{1}$, tuti.purwati@unsoed.ac.id², \\ chusni.hadiati@unsoed.ac.id ${ }^{3}$
}

Article History:

First Received:

$28 / 05 / 2020$

Final Revision:

$28 / 06 / 2020$

Available online: $30 / 06 / 2020$

\begin{abstract}
This research focuses on the legitimacy of Donald Trump's speech in declaring Jerusalem as the capital city of Israel on December 2017. This research aims to: (1) identify the text structure of the speech, (2) describe the social cognition of this speech, (3) and to reveal the social context of this speech. The compiled data is analyzed by using Van Dijk's CDA theory of sociocognitive (1988). This theory has interrelated three dimensions of analysis consisting of text structure, social cognition, and social context. The method of this research is qualitative by using the descriptive analysis. The data source of this research is the speech text of Donald Trump declaration speech of Jerusalem as Israel's capital on December 2017. The result of this research shows that there is semantic aspect (microstructure) used by Donald Trump: Background (7), Detail (4), and Presupposition (15). From the analysis, the researcher argues that Donald Trump tends to be proIsrael. This is supported in the structure of the text by how it consistently uses direct language to influence the emotional attachment of the intended by using logical facts and emotional involvement to make negative out-group representations to get positive representations to them and their allies. Furthermore, social cognition reveals the ideology and partisanship of Donald Trump about this conflict. It can be identified clearly by correlating the context of this speech to something that related to IsraelPalestine conflict. In social cognition, as the president of the United States of America, Donald Trump has a massive influence to the international world, even though it caused pros and contras for all elements of society. Possible further research about critical discourse analysis can be conducted by analyzing other issues. In short, it is also a suggestion to the other researchers to investigate more variation data such as news, advertisement, movie, and so on.

Keywords: Critical Discourse Analysis, Socio-cognitive approach, Ideology, Speech, Jerusalem.
\end{abstract}




\section{INTRODUCTION}

Speech is a manifestation of power. By speech, the speaker can influence people to change their viewpoints and behaviors. When people form impressions about others, they are mostly influenced by the power of speech. By using speech, the speaker is able to convince the society that the speaker stands beside them and have the same thought. This strategy can gain sympathy from people. When they are able to obtain sympathy, the succession in gaining power soon come through (Van Dijk, 2008: 43).

One of the fields that harness the power of speech is in politics. Politics is an activity related to influencing the actions and policies of a government or getting and keeping power in a government or society. One of the aims of politics is to involve the use of power to another by affecting their behavior. In politics, people need political strategy and the method to do it varies depending on the purpose. According to Giddens (2006: 884), politics concerns the way power is used to influence the scope and content of government activities. Power in society directly influences power in the state, but political impact also changes the distribution of power in society. The concept of politics draws attention to the fact that every social system has a power structure, not just those whose social functions are formally defined in terms of power. Because all areas of social life involve elements of power, politics cannot be seen to only involve 'what politicians do'. Instead, any process that involves the implementation of controls, constraints and coercion in a potentially political society.

On the other hand, Critical Discourse Analysis (CDA) is the most effective way to reveal the rhetorical and legitimacy that delivered by someone. Ideology may be able to be expressed in the form of text and speech. The discourse function is to persuade people and confirm the present ideologies. It means that critical discourse analysis can reveal the structure of ideology. Besides, structure of ideology is divided into In-group represents in positive term that symbolized with "we and us". In speech for In-group, this group always delivers specific idea for positive action. Moreover, the speaker uses general and abstract idea for negative representation to bias the information that catch by people. Euphemistic term and attributes to circumstances beyond our control event and be victim for out-group action. On the contrary, out-group represents in negative term that is symbolized with "them and they". In speech for out-group, the speaker describes general and abstract idea to describe positive act of out-group. The speaker also describes specific idea and blames the out-group for the negative act.

Moreover, the critical discourse analysis theory that is going to use in this analysis is socio-cognitive analysis model proposed by Teun A. Van Dijk (1988). Socio-cognitive divided into text structure, social cognition, and social context. Text structure has three categories; namely superstructure, macrostructure and microstructure. The superstructure is the part of the discourse structures which is related to the framework or scheme of the text and elements of the text which are arranged to be a good and complete text such as opening, content, and closing, macrostructure is the general meaning of the text which can be seen or analyzed by the topic or theme, and microstructure concern with the meanings of discourse by investigating and analyzing words, sentences, propositions, and phrases (Van Dijk, 1988: 31). Then, social cognition concerns at how a text is produced. It consists of person scheme, self-scheme, role scheme, and event scheme. Lastly, social cognition is to show how the shared meaning produced from practical discourse and legitimacy that consists of power practice and access. Ideology belongs to all groups of people, and Donald Trump as the president of United States of America also has his own ideology in delivering the speech when he declared Jerusalem as capital city 
of Israel.

Donald Trump becomes a popular politician in America, even in international politics among his controversial policy since he was the candidate of president of the USA when he said about to build border wall to prevent the immigrants and forbid the Muslims to enter the USA. The way he delivered his speech has been the formula for political success. Furthermore, becoming the president of powerful country should make him more aware and careful to construct his speech in order to gain support from citizens. In his speech, there are many interesting things which become his political strategies. Hence, Trump with all his controversy makes his speech is adorable to analyze. One of the popular speeches that he conducted is about his declaration speech of Jerusalem as the capital city of Israel on December, $6^{\text {th }} 2017$ at the White House.

Trump has opposed global opposition by recognizing Jerusalem as the capital city of Israel. However, he insisted that the controversial move would not derail his own administration's bid to resolve the Israeli-Palestinian conflict. Trump and Netanyahu, the Prime Minister of Israel, have the same outlook in order to address the city of Jerusalem as the capital city of Israel. The declaration of Jerusalem in December would aggravate further the alliance between Palestinians and Arabs. Moreover, the relocation of the U.S embassy to Jerusalem became an offensive sign to the Arab-Palestine alliance for the status of Jerusalem issue in what is often described as the world's most intractable conflict. That is a problem that has frustrated several attempts at peace efforts for decades. Both Israelis and Palestinians demand that Jerusalem be the capital of their country, now and in the future, and that status is not negotiable.

Indubitably, Trump's declaration triggered an international response. The United Nations chose to condemn President Donald Trump's decision to recognize Jerusalem as the capital of Israel despite threats from the US to withdraw funds from world organizations. Around 128 countries voted for the resolution, while nine chose "no", and 35 abstained, including Canada, Mexico and Australia. The vote came after the US Ambassador to the US Nikki Haley issued a direct threat, saying that the US would think twice about funding the world body if it chose to condemn its decision. Few countries seemed cowed, as nation after nation blasted the U.S. at the emergency session of the U.N. General Assembly, condemning the Jerusalem decision as illegal, destabilizing, and a violation of international law.

The following is a pre-analysis of Van Dijk's socio-cognitive analysis concept which consists of three dimensions, namely text analysis, social cognition, and social context that are going to be applied in this present study.

The first dimension is text analysis. In this pre-analysis, semantic is used in order to explain the data. There are explicit and implicit meanings in critical discourse analysis, and semantic analysis aims to find the meaning of texts in semantic style analysis. In the semantic aspect, there are three main points elaborated; they are background, detail, and presupposition. The meaning of the text can be seen from one of semantic style which are background elements.. 


\begin{abstract}
"It would be folly to assume that repeating the exact same formula would now produce a different or better result.

Therefore, I have determined that it is time to officially recognize Jerusalem as the capital of Israel.

While previous presidents have made this a major campaign promise, they failed to deliver. Today, I am delivering."
\end{abstract}

The above paragraph shows the background that the speaker wants to clarify the self-attribution of his argument about their previous president. Trump uses irony to describe previous leaders, such as "While previous presidents have made this a major campaign promise, they failed to deliver. Today, I am delivering". Therefore, to support his statement about past failure that was done by the previous presidents, Trump said that he considered the previous presidents had failed in carrying out his duties to reconcile peace between Israel and Palestine, so he clearly discredited the previous presidents by showing his work which actually moved the U.S embassy to Jerusalem as an effort to peace of both sides. Following the initial sentence, the background is elaborated using negative perception word representation such as "folly" and "failed". Those negative word representations easily will influence the addresses that have not known the background and the fact before. Thus, the background used by him to express his disappointment with the past failure has the main aims to give the negative representation of the previous presidents. This strategy is often used by Trump to impress the addressee toward his action and regulation.

The second one is social cognition dimension. On the dimension of social cognition, what is observed that is the production process of a text that involves the individual cognition of the writer. Van Dijk mentions that events are understood based on the scheme. Schemes are conceptualized as mental structures which include how we view humans, social roles, and events. There are several types of scheme that can be described, namely person scheme, self-scheme, role scheme, and event scheme. The following is an example of social cognition dimension from role scheme.

This scheme relates to how a person sees and portrays the role and position occupied by a person in society. In this speech, Donald Trump looked at the previous president of the United States as a state leader who failed to realize his political promises, especially about the recognition of Jerusalem as the capital of Israel. As in the explanation of the person scheme before, one of Donald Trump"s characters in the speech was to discredit his political opponents, in this case, the previous president of the United States. He assumed that delaying the recognition of Jerusalem as the capital of Israel would not produce anything. He said, "it would be folly to assume that repeating the exact formula would now produce a different or better result." The former president he referred to was Bill Clinton, George W. Bush, and Barack Obama.

The last dimension is the social context that develops in society about a problem. According to Van Dijk, in the analysis of society, there are two important points: power, and access. The following is an example of social context analysis in terms of access. Access is when the one who has the right or opportunity to use the 
benefit for legitimate something. His speech aimed to recognize Jerusalem as the capital of Israel. Donald Trump said that this is the right step in the efforts of peace between Israel and Palestinians for one of the most intractable conflicts to solve in the world. As the president of United States, he has a big influence in determining and implementing his foreign policy. Moreover, he is the president of a superpower country that has enormous influence in the international world; each of its policies will greatly influence other countries. As the president of a superpower country, Trump has great access in determining and implementing his foreign policies, including in the Israeli-Palestinian conflict. Through his position, access to influence the attitudes of other countries and the international community become great, especially as the speech has spread in various national and international mass media.

Departing from the background above, it is necessary to conduct an in-depth study of the Trump's declaration speech to the Jerusalem issue to find out what the actual speech using socio-cognitive analysis theory proposed by Teun A. Van Dijk and to acknowledge the tendency of Trump's declaration speech. This research will analyze Trump's speech that related to the ideology and power relation in order to find his aims in doing it as well.

There are several reasons why researchers take Donald Trump's political declaration speech as the object of this study. First, political speech may indicate a power relationship as Van Dijk (1995: 17-28) states that political actors as the dominant institutional elite have power and legitimacy towards others. Second, political speeches can persuade others to delegitimize people discursive to convince others through ideological construction. Finally, political actors mainly talk about various topics such as society, culture, economics, and military, which can convey the existence of power relations through utterances for convincing arguments in each topic. Therefore, researchers used critical discourse analysis with the socio-cognitive theory proposed by Teun A. Van Dijk to analyze political speeches about the structure of texts and ideologies used by political speakers, which show ideologies and power relations.

\section{RESEARCH METHOD}

This study of Donald Trump's declaration speech of Jerusalem as capitalcity of Israel belongs to qualitative research is a descriptive qualitative research. This research is qualitative since it complies with characteristics of qualitative research. Moleong (in Arikunto, 2010: 22) explained that qualitative research normally deals with spoken or written materials.

The data of this research are Donald Trump's utterances in his speech on $6^{\text {th }}$ December 2017 at White House. The data is acquired from CNN media and the supporting data of this research is the transcript and the summary of the speech from White House government website. Data are collected based on Creswell (2007: 118) that data collection is a series of interrelated activities aimed at gathering useful information to answer research questions that arise.. The steps that are conducted by the researcher are finding the data, collecting data by watching the video to verify its transcript, categorizing the data which is in the form of script, and identifying each utterance with socio-cognitive analysis proposed by 
Van Dijk.

The data analysis is done by the following steps. Data are classified based on text structure i.e. superstructure, macrostructure, and microstructure. Next, the researcher analyzes the social cognition dimension which related to the production of the text to show the shared meaning produced from practical discourse and legitimacy. Then, the researcher examines reflection of ideology of Donald Trump towards Israel-Palestine conflict. Lastly, the researcher draws final conclusion dealing with the previous analysis with using description about the text (macrostructure, superstructure, and microstructure), social cognition, and social context with using critical discourse analysis of socio-cognitive analysis concept proposed by Van Dijk.

The researcher uses the datasheet as a secondary instrument to help him analyze the data. The format of the datasheets is illustrated in the following table.

\begin{tabular}{|c|c|c|c|c|}
\hline \multirow{2}{*}{ No } & \multirow{2}{*}{ Text } & \multicolumn{3}{|c|}{ Semantic aspects } \\
\cline { 3 - 5 } & & BG & DET & PRE \\
\hline 1 & & & & \\
\hline 2 & & & & \\
\hline 3 & & & & \\
\hline
\end{tabular}

\section{Example of classifying the data of microstructure}

$\begin{array}{ll}\text { BG } & : \text { Background } \\ \text { PRE } & \text { : Presupposition } \\ \text { DET } & \text { : Detail }\end{array}$

\section{RESULT AND DISCUSSION}

Text Structure

The first subchapter shows the result of the text structure object. Van Dijk mentions that there are 3 types of text structure categories. It consists of superstructure, macrostructure, and microstructure. It includes the data display of the discourse structure and the table of the frequency of the microstructure category.

The first structure is superstructure category that is divided into 3 categories. Since the object of the data is speech text, the researcher decides to use Cicero's theory that divided into 3 parts which include opening, content, and closing. In the opening part, Donald Trump delivers the reason of his decision to move the United States' embassy from Tel Aviv to Jerusalem. Then, in the content part he explains the detail of his decision to convince the addressee. Lastly, in the closing part he delivers his hope and persuaded people to join with him.

The second one is macrostructure category. Macrostructure focuses on global meaning, which emphasizes more on the theme or main topic of discourse. The researcher found that the main topic of this speech is "Donald Trump's administration of United States recognition of Jerusalem as the capital city of Israel". The last is microstructure category. Microstructure analyzes the words, sentences, phrases, and diction of the speech text. The researcher found a total of 
26 data, consisting of the semantic aspect is divided into background (7), detail (4), and presupposition (15). The researcher displays table to classify the data in the microstructure category to show the frequency of the structure as well.

\begin{tabular}{|c|c|c|c|}
\hline \multirow{2}{*}{$\begin{array}{c}\text { Microstructure } \\
\text { category }\end{array}$} & \multicolumn{3}{|c|}{ Semantic Aspect } \\
\cline { 2 - 4 } & BG & DET & PRE \\
\hline Result & 7 & 4 & 15 \\
\hline Total & \multicolumn{3}{|c|}{26} \\
\hline
\end{tabular}

The result of the data
BG : Background
DET : Detail
PRS : Presupposition

\section{Superstructure}

\section{Opening}

Donald Trump states that his decision to recognize Jerusalem as the capital of Israel is to solve problems and to answer the challenges of the world in the future as a peace effort between Israel and Palestine. As the beginning to explain the contents of his speech, he started it with the discourse on the movement of the United States embassy to Jerusalem which is based on Jerusalem Embassy Act in 1995 and passed in Congress by majority of his bipartisan, and finally have been carried out after the senate's voting process which took 6 months. In this opening he also blames the previous presidents who are too slow in taking action to move the United States embassy for more than 20 years. He considers the previous presidents as failure in an effort to reconcile Israel-Palestine. Therefore, repeating the mistakes of the previous presidents will not answer the peace efforts between the both sides, thus why Donald Trump considers his decision in recognizing Jerusalem as the capital of Israel is a success in the peace effort.

\section{Content}

Content is a core part of what is discussed in a speech. In essence, the content in this speech is an explanation of the background presented at the opening. In the content of the Donald Trump's speech, he stresses the recognition of Jerusalem as the capital of Israel and explains it in more detail about the history of Israel recognition as a country carried out by President Truman. In the beginning, he says that Israel has the right to its sovereignty to determine its own capital, and then he also argues that recognizing Israel as the capital is a necessity to achieve peace. He orders to immediately move the United States embassy by involving various construction workers. He realizes that Jerusalem is one of the most sensitive issues, so his administration supports a two-state solution to reach an agreement.

\section{Closing}

Donald Trump reiterates that his decision in recognizing Jerusalem is for the sake of peace between Israel and Palestine, and to end all the violence that happened for a better future as mentioned in the content part. He also persuades all states and religious leaders to take a part in peace efforts between the two parties. At the end of his speech, he prays for all parties to get support from the society because he 
wants to show that he also gets supported by many parties so that all of this can be run smoothly. Then as the character of closing in speech, he closes the speech with a thank.

\section{Macrostructure}

After reading the entire speech, the researcher concluded that the central theme in this speech was "Donald Trump's administration of the United States' recognition of Jerusalem as the Capital of Israel." This speech conveyed the central theme of Israel's glorification, which made this country worthy of getting Jerusalem as the capital shown by this speech scheme.

\section{Microstructure}

In this section, the researcher describes the linguistic features used by the speaker to manipulate the language. The researcher chooses semantic aspect to make this research more focused.

\section{Background}

Background is element of speech that can influence meaning delivered to public. This element also can uncover the purpose of the speaker since background is depends on speaker who deliver the speech. In the speech text that Donald Trump delivers there is background which can be analyzed. Background of the speech is as follow:

Data.1

In 1995, Congress adopted the Jerusalem Embassy Act, urging the federal government to relocate the American embassy to Jerusalem and to recognize that that city - and so importantly - is Israel's capital. This act passed Congress by an overwhelming bipartisan majority and was reaffirmed by a unanimous vote of the Senate only six months ago.

The underlined text above shows that Donald Trump tries to tell the background by showing the bill of the U.S that support his decision about recognition of Jerusalem as capital city of Israel. This bill named Jerusalem Embassy Act, which passed by Congress in 1995 as legal basis for the U.S to move its embassy and called for Jerusalem to remain an undivided city (www.congress.gov). He shows the bill of Jerusalem Embassy Act to convince the society about his decision because it has legal standing, so it is not the arbitrary act from Donald Trump. In order to strengthen the fact, he uses the other evidence that this decision also supported by the Congress and the Senate. Therefore, this background has purpose to looking for support from the society and international world.

\section{Detail}

Detail relates with information control from communicator. It is the communicator's strategy on how he expresses his attitude explicitly and implicitly about the information processed.

\section{Data.2}

We cannot solve our problems by making the same failed assumptions and repeating the same failed strategies of the past. 
This statement has implicit intention to blame the previous presidents as a failed government which does not give any impact for Israel and Palestine reconciliation. Of course, there is imbalance information about the previous presidents. Even though the utterance above is an argument, but it can influence the addressee's thoughts about him and the previous presidents. It becomes his speech character when he blames the out-groups to make him looks superior.

\section{Presupposition}

Presupposition is statement that can be used to support the meaning of the text. Theoretically, a presupposition B of a sentence A is a presupposition that is entailed by $\mathrm{A}$ and by non-A. It is a statement used to support meaning of a text by giving credible premise (Van Dijk, 1988: 63).

Data.3

We cannot solve our problems by making the same failed assumptions and repeating the same failed strategies of the past.

By saying "solve our problems", Donald Trump tries to interpret that the problem he means is not only the government's problem, but also the problem of the United States and its citizens. Then, the utterance "the same failed assumptions and repeating the same failed strategies of the past" means that the procrastination to recognize Jerusalem as capital city of Israel is a wrong decision which done by the previous government, so that he blames the previous presidents as the failed ones implicitly.

\section{Social Cognition}

The researcher examines based on the scheme in a discourse consisting of person scheme, self-scheme, role scheme, and event scheme. The person scheme examines how Donald Trump portrays the groups that he means, the self-scheme is how he describes himself, the role scheme relates to how previous presidents is perceived as failed president, and the event scheme is how the speaker tells the origin of the United of States recognition to Jerusalem as capital city of Israel. These schemes are used to look for implicit meanings contained in the speech.

\section{Self-Scheme}

In this scheme, the researcher analyzes the figure of Donald Trump who is able to influences audiences in regard to his policies. He delivers a speech represents the United States. It is proven by the representations of the words "I", "my", and "we" that can be found in the contents of this speech, which is a form of Donald Trump's representation of the United States that invites state leaders, religious leaders, and the world communities to take part in peace efforts between Israel and Palestine. The use of the word 'we' is used because Donald Trump is part of American society and wants to gives a closer impression to the addressee. 


\section{Person Scheme}

This scheme determines Donald Trump's mentality in assessing other groups. In his speech, Donald Trump looked at three groups: the previous American president, Israel, and terrorist in Middle East. He views Israel as the party supporting his policy, while the previous presidents of the United States as his outgroups. Besides, from the policies that will be implemented, he promises a new approach in the Israeli-Palestinian conflict. From this person scheme, it can also be seen how the role scheme contained in the speech.

In every occasion of speech or interview, it has been Donald Trump's characteristic since the campaign days that he always highlights the shortcomings of the previous presidents so that he looks superior in the eyes of his supporters. In this speech he did it as well. He argues in his speech that for more than 20 years, every American president had previously only made law's waiver and refused to move the United States embassy to Jerusalem and recognize it as the capital. Definitely, the presidents who referred by Trump was Bill Clinton, George W. Bush, and Barack Obama, remember the Jerusalem Embassy Act was passed in 1995 when Bill Clinton's administration. During their administration, it was the fact that the discourse on the movement of the U.S embassy was not realized, even though during the Obama administration he had recognized Jerusalem as the capital of Israel but had no significant impact.

\section{Role Scheme}

In this speech, Donald Trump looks at the previous president of United States as a state leader who failed to realize his political promises, especially about the recognition of Jerusalem as the capital of Israel. As in the explanation of the person scheme before, one of Donald Trump's characteristics in the speech is to discredit his political opponents, in this case the previous president of the United States. He assumes that delaying the recognition of Jerusalem as the capital of Israel would not produce anything, as he states "it would be folly to assume that repeating the exact formula would now produce a different or better result." The former president he referred to are Bill Clinton, George W. Bush, and Barack Obama.

\section{Event Scheme}

The event scheme is almost similar to the analysis of the social context, but certainly different. The event scheme more often tells the origin of the recognition of the United States of Israel as a sovereign country. Among the events presented by Donald Trump, there was an incident where the formation of an Act that made the United States increasingly assists Israel in its efforts to legitimate Jerusalem called Jerusalem Embassy Act.

\section{Social Context}

The final analysis is the social context. Social context consists of power practice and access. Power practice is how Donald Trump harnesses his power as president of the United States and access is how he takes advantage and propagates his idea to society. The researcher analyzes based on the context of the speech. 


\section{Practice of Power}

Donald Trump, in his declaration speech of Jerusalem as the capital of Israel, delivers his ideas with the aim of convincing and influencing the addressee so that the addressee understands and possibly supports the policies that Donald Trump applies. His speech also intended to influence the addressee to believe that what he is doing is merely for peace's sake between Israel and Palestine, in which he calls it as a new approach. In order to convince his addressee, he expresses his opinion about Israel and some facts about Jerusalem as a sanctified city by three religions. He delivers straightforwardly and clearly to show the impression of seriousness in carrying out this policy. Even though he realizes that not everyone would support this policy and cause controversy.

\section{Access}

The declaration speech was delivered on December 6, 2017 and it is a speech aimed to declare the U.S recognition of Jerusalem as the capital of Israel. Donald Trump states that this is the right step in the efforts of peace between Israel and Palestinians for one of the most intractable conflict to solve in the world. As the president of United States, he has a big influence in determining and implementing his foreign policy. Moreover, he is the president of a superpower country that has enormous influence in the international world; each of its policies will greatly influence other countries. Evidently, several of his foreign policies have caused controversy and even criticism from various groups such world leader, international organizations, politicians, and the international community.

\section{CONCLUSION}

The first dimension is the structure of the text, which has several parts, such as superstructure (schematic), macrostructure (thematic), and microstructure (linguistic analysis). The macrostructure (thematic) of the speech is about Donald Trump's administration of United States recognition of Jerusalem as the capital of Israel. In the opening, Donald Trump delivers the background of his administration's decision to recognize Jerusalem as the capital city of Israel as a new approach of peace effort between Israel and Palestine. Then, the contents of his speech are explained elaborately regarding the reason for the recognition of Jerusalem, the history of Israel, and the challenges of peace effort between Israel and Palestine. Lastly, he closes the speech by persuading the religious and political leaders with the lasting peace of Israel - Palestine, and praying to all parties for the sake of this policy.

This research deals with microstructure (linguistic analysis) that makes and helps the addressees understand the communicator messages. There are seven topics changing in Donald Trump's speech, and the topics itself have the purpose to gives the advantage to him and Israel to ensure the society about their policy. The researcher found 4 data in detail aspect, and it has the function to delivers the information explicitly if it has a beneficial impact for him, while the disadvantage information implicitly delivered. Last, the researcher found 15 presuppositions in this speech. In social cognition, the researcher finds information about Donald Trump's administration, the bilateral relationship between the United States and 
Israel, the failure of previous presidents of the United States toward Israel-Palestine conflict, and the history and problems of Israel-Palestine conflict. This part also reveals the ideology and partisanship of Donald Trump about this conflict. It can be identified clearly by correlating the context of this speech to something related to the Israel-Palestinian conflict. As a result of this analysis, the researcher found that his administration stands for Israel. In a social context, there is a practice of power and access. As the president of the United States of America, Donald Trump has a massive influence on the international world, even though it causes pros and contras for all elements of society. He has tremendous access as the superpower country president, so it eases him to get attention from all over mass media in the world.

\section{REFERENCES}

Arikunto, Suharsimi. (2010). Prosedur Penelitian, Suatu Pendekatan Praktik (edisi revisi). Jakarta: PT. Adi Mahasatyma

Brown, G., \& Yule, G. (1983). Discourse Analysis. Cambridge: Cambridge University Press.

Creswell, J.W. (2007). Qualitative Inquiry and Research Design: Choosing Among Five Approaches. United States of America: SAGE.

Dijk, T. A. (1980). Macrostructures: An Interdisciplinary Study of Global Structures in Discourse, Interaction, and Cognition. New Jersey: Lawrence Erlbaum Associates, Inc., Publishers

(1988). News as Discourse. New Jersey: Lawrence Erlbaum Associates Publishers.

1 p. $17-27$

(1995). "Aim of Critical Discourse Analysis." Japan Discourse vol.

. (1996). Text and Practices: Readings in Critical Discourse Analysis.

London: SAGE.

. (1998). Ideology: A Multidisciplinary Approach. London: SAGE

(2001). The Handbook of Discourse Analysis. Oxford: Blackwell Publishers.

(2004). Text and Context of Parliamentary Debates, in P. Bayley (ed.) Cross-cultural Perspective on Parliamentary Discourse. Amsterdam: Benjamins.

. (2006). Discourse, Context, and Cognition. London: SAGE.

. (2008). Discourse and Power. New York: Palgrave Macmillan.

Eriyanto. (2001). Analisis Wacana Pengantar Teks Media.

Yogyakarta: LkiS. Fairclough, Norman. (2001). Language and Power.

London: Longman

Fairclough, N., \& Wodak, R. (1997). Critical Discourse Analysis. In T. Van Dijk (Ed.), Discourse Studies: A Multidisciplinary Introduction Vol. 2. London: Sage. Giddens, Anthony. (2006). Sociology $5^{\text {th }}$ Edition. Cambridge: Polity Press. 
Head, Brian William (1985). Ideology and Social Science: Destutt de Tracy and French Liberalism. Dordrecht: Martinus Nijhoff

Hendrikus, P. Dori Wuwur. (1991). Retorika: Terampil Berpidato, Berdiskusi, Berargumentasi, Bernegosiasi. Yogyakarta: Kanisius.

Higgot, R., \& Proud, V. (2017). IFA Edition Culture and Foreign Policy: PopulistNationalism and Foreign Policy (Cultural Diplomacy, International Interaction and Resilience). Stuttgart: IFA (Institut für Auslandsbeziehungen).

Hornby, A.S. (2010). Oxford Advanced Learner"s Dictionary of International Student Edition. $8^{\text {th }}$ Edition. Oxford: Oxford University Press

Pennycook, Alastair. (1997). Critical Applied Linguistics and Education. Sydney: Springer Science+Business Media LLC.

Renkema, Jan. (2004). Introduction to Discourse Studies. Philadelphia, PA, USA: John Benjamin"s Publishing Company.

Sugiyono. (2009). Metode Penelitian Kuantitatif, Kualitatif dan R\&D. Bandung: Alfabeta.

Sulfiyani. (2014). The Study of the Jakarta Post"s Tendency inf Reporting Israel Palestine Conflict on November 20 th 2012: A study of Critical Discourse Analysis. Purwokerto: Faculty of Social and Politic Jenderal Soedirman University.

Yule, George. (1996). The Study of Language: An Introduction. Cambridge: Cambridge University Press.

\section{Internet Sources}

Article entitled "In the Trump Era, Evangelicals Take Center Stage on Israel Policy", retrieved from https://www.nbcnews.com/politics/white-house/trump-eraevangelicals-take-center-stage-israel-policy- $n 99432 .$, Tuesday, $2^{\text {nd }}$ January 2020; 11:17 a.m.

Article entitled "What makes Jerusalem so Holy?", retrieved from https://www.bbc.com/news/world-middle-east-26934435., Tuesday, $14^{\text {th }}$ January 2020; 01:23 p.m.

Impasse at Camp David: the Overview; Clinton Ends Deadlocks Peace Talks, retrieved from https://www.nytimes.com/2000/07/26/world/impasse-atcamp-david-the-overview-clinton-ends-deadlocked-peace-talks.html, Friday, $26^{\text {th }}$ July, 2019; 08:27 p.m.

Noam Chomsky: The Israel-Palestine conflict (video), retrieved from https://www.youtube.com/watch?v=DxSO2MICDuM, Wednesday, $12^{\text {th }}$ July 2019; 10:20 p.m.

(https://edition.cnn.com/videos/politics/2017/12/06/trump-jerusalem-remarksfull.cnn). 